\title{
Simulation of SOFCs based power generation system using Aspen
}

\author{
Paulina Pianko-Oprych*, Mateusz Palus \\ West Pomeranian University of Technology, Szczecin Institute of Chemical Engineering and Environmental Protection \\ Processes, Faculty of Technology and Chemical Engineering, al. Piastów 42, 71-065 Szczecin, Poland \\ "Corresponding author: e-mail: paulina.pianko@zut.edu.pl
}

\begin{abstract}
This study presents a thermodynamic Aspen simulation model for Solid Oxide Fuel Cells, SOFCs, based power generation system. In the first step, a steady-state SOFCs system model was developed. The model includes the electrochemistry and the diffusion phenomena. The electrochemical model gives good agreement with experimental data in a wide operating range. Then, a parametric study has been conducted to estimate effects of the oxygen to carbon ratio, $\mathrm{O} / \mathrm{C}$, on reformer temperature, fuel cell temperature, fuel utilization, overall fuel cell performance, and the results are discussed in this paper. In the second step, a dynamic analysis of SOFCs characteristic has been developed. The aim of dynamic modelling was to find the response of the system against the fuel utilization and the $\mathrm{O} / \mathrm{C}$ ratio variations. From the simulations, it was concluded that both developed models in the steady and dynamic state were reasonably accurate and can be used for system level optimization studies of the SOFC based power generation system.
\end{abstract}

Keywords: Solid Oxide Fuel Cell system, modelling, methane, reforming, $\mathrm{CPO}_{\mathrm{x}}$.

\section{INTRODUCTION}

Commercialization of Solid Oxide Fuel Cells based generation system is highly dependent on the system performance, configuration, maintenance requirements and costs. Huge efforts being undertaken to increase the SOFC technology performance as well as to reduce the manufacturing costs ${ }^{1}$. However, the application of this technology still needs further attention particularly in the system scale design. To analyse this technology at the design stage in an effective way, several mathematical models for both the steady-state and dynamic conditions have been already presented ${ }^{2-4}$. One of the first was an Aspen Plus model of a tubular internal reforming SOFC technology developed by Zhang et al. ${ }^{2}$. The model based on existing Aspen Plus functions and unit operation models, which were used both for the fuel reformer, heat exchangers, afterburner as well as for SOFC model. In addition, calculator module was applied in the Aspen Plus to calculate the molar flow rate of required oxygen delivered to the SOFC stack as well as to estimate the value of expected fuel utilization factor. Moreover, to predict cell performance, the cell voltage calculation was performed by implementation in the Aspen Plus additional block function using a Design-Specs module. This block calculated the voltage, current and amount of fresh fuel for producing the desired power output ${ }^{2}$. A further example of the application of commercial process simulators including Aspen Plus software was presented by Ameri and Mohammadi ${ }^{3}$ for a model of SOFC and gas turbine hybrid system. The simulation results showed that the cycle can achieve high electrical generation efficiency of $68.2 \%$, which was very attractive in comparison to the ideal efficiency of combined cycle power plants of $50 \%$. Authors ${ }^{3}$ proved that the parametric analysis performed using the developed Aspen Plus model for SOFC and GT, gas turbine, hybrid system can helps to understand the effects of the variation of operating parameters on the SOFC's performance in an easy and time saving manner. It was found that the key point in the study was to determine the conditions of the fuel reforming by testing different values of the steam to carbon ratio. The $\mathrm{S} / \mathrm{C}$ ratio should remain at low values as long as it can meet the carbon formation and thermal gradient limits of the SOFC. In addition, the right choice of the steam to carbon ratio enables resignation from the additional auxiliary system to produce steam for injection into the fuel cell reformer. Anderson et al. ${ }^{4}$ presented an adaptable model for the methane fed internal reforming SOFC based system using the Aspen. Three methods for modelling the methane reforming in the SOFC were considered including the equilibrium model, the 2-stage PFTR model and the recycled reforming model. The electrochemistry, diffusion phenomena and reforming kinetics were included in the models. From the comparison of the model results with experimental data in wide temperature and pressure conditions it was concluded that the recycled model was reasonably accurate in the steady state analysis. The technical feasibility of Combined Heat and Power system, CHP, composed by orange peels steam/ air gasification unit coupled with a Solid Oxide Fuel Cell was investigated also by Galvagno et al. ${ }^{5}$. A zerodimensional process simulation model using Aspen Plus simulator was used to analyze the combined system. The comparison between the polarization curve obtained by Doherty et al. $^{6}$ and the SOFC model ${ }^{5}$ showed a good agreement. Independently, Doherty et al. ${ }^{6}$ carried out sensitivity analyses of performance of a tubular SOFC stack on wood and miscanthus syngas under various operating conditions using equilibrium model based on Gibbs free energy minimisation developed in Aspen Plus. The model performed mass and heat balances and considered ohmic, activation and concentration losses for the voltage calculation. Ohmic loss was calculated from equations reported by Song et al. ${ }^{7}$, while Achenbach's semi-empirical correlations were implemented to determine the activation $\operatorname{loss}^{8}$. The concentration loss was calculated based on the equation derived by Chan et al. ${ }^{9}$. The simulation results indicated that the cell voltage decreased slightly with fuel utilisation factor due to increased voltage losses (ohmic, activation and concentration). The current density increased slightly due to the higher amount of hydrogen consumed on the 
anode. It was noticed that the fuel flow rate required to achieve the desired power of $120 \mathrm{~kW}$ DC decreased with fuel utilisation factor. Efficiency was found to be very sensitive to changes in fuel utilisation factor. The gross $\mathrm{AC}$ and net AC efficiencies increased by 18.6 and 17.96 percentage points respectively over the fuel utilisation factor range ${ }^{6}$. The SOFC stack should be operated at low steam to carbon and high fuel utilisation factor. In addition, varying current density had significant influence on the system. Increasing the current density from 50 to $420\left[\mathrm{~mA} \cdot \mathrm{cm}^{-2}\right]$ decreased both efficiency and voltage, but increased power. With regard to operating cost it was desirable to operate the SOFC stack at a high voltage and efficiency, however it was also desirable with regard to capital costs to operate the SOFC stack at high power due to the fact that less SOFCs needed. Therefore, it was concluded that there have to be a trade-off between voltage, efficiency and power with respect to current density to match efficiency and costs ${ }^{6}$. Numerical analysis of the complete system including fuel processor, SOFC stacks and Balance of Plant, BoP, components fed by biogas were performed by Kupecki et al. ${ }^{10}$. Two identical commercial electrolyte supported SOFC stacks in parallel and in-series connections were evaluated in Aspen HYSYS 8.0. With two stacks in series, the first stack operated as a primary electrical generator and second unit operating at relatively low current of 0.2 $\left[\mathrm{A} \cdot \mathrm{cm}^{-2}\right]$ and was used to boost the electrical efficiency. It was found that electrical efficiency of the system with two in-series SOFC stacks was higher by $3-7 \%$ points in comparison with system based on parallel connection of two stacks. Barelli et al. ${ }^{11}$ performed an energeticexergetic comparison between two micro-cogenerative CHP units for residential applications based on Solid Oxide Fuel Cell and Proton Exchange Membrane Fuel Cell, PEMFC. Simulations of two zero-dimensional models in Aspen Plus were conducted in order to indicate the most efficient fuel cell technology for micro-CHP systems by characterization constant electrical power and thermal demand. The value of electrical power was set equal to the standard request of a residential application of $3\left[\mathrm{~kW}_{\mathrm{e}}\right]$, while for the CHP section the temperature of the hot water sent to the user was equal to 338.15 $[\mathrm{K}]$. It was found that the values of electrical efficiency were better for the SOFC system in all considered cases of operating temperatures and pressures. However, this difference narrowed in cases of pressurized PEMFC at low operating temperature.

According to the introduction many publications were related to the CHP systems based on fuel cells technolo$\mathrm{gy}^{3,5,7,10-11}$. These studies investigated the performance and operational characteristics of the various systems in order to establish the best configuration with respect to efficiency and economics. Identified by numerous research groups electrochemical models implemented into commercial available process simulators gave good agreement with experimental data. These models were extremely useful in understanding the system level interactions, implications for system performance and model aided design. Moreover, models helped in evaluating alternative system configurations in an integrated design.

Therefore, in the present study a thermodynamic, zero dimensional SOFC based system model is developed by using existing Aspen Plus V8.6/Aspen Dynamics V8.4 functions and units operation models in combination with additional user defined subroutines. Subroutines have to incorporate SOFC phenomena such as chemical and electrochemical reactions as well as heat and mass transfer and are implemented via calculator blocks written in FORTRAN. The SOFC model has been developed based on the proposition presented by Zhang et al. ${ }^{2}$. The model was validated with experimental data ${ }^{17}$. Then, a parametric study was carried out to investigate the influence of the oxygen to carbon ratio on the SOFCs system performance. Finally, the system model was modified in the transient mode to evaluate the system response on operating conditions variations. This approach fully utilizes the existing capabilities of the process simulator and provides a convenient tool to perform detailed thermodynamic and parametric analysis of SOFC based power generation system.

\section{NUMERICAL APPROACH}

A simulation of the steady state SOFC system has been constructed in Aspen Plus environment using standard, built-in unit operation modules and functions. The plant layout used for the simulations of the SOFC based generation system includes the following components: reformer, SOFC stack characterized by separate modules for the anode and cathode, heat exchanger, burner and recuperator. The last three components allow the heating or cooling of the fuel cell, the heat recovery from the exhausted gases and the fulfillment of thermal demand. In particular, the recuperator called "RECUPER" allows the maintenance of the fuel cell operating temperature by heating the air sent to the cathode. The additional heat exchanger "HEATER-1", in which takes place the heat exchange, allow to heat the stream of oxygen "O2" entering to the anode. A schematic diagram of the SOFCs based generation system under investigation is given in Figure 1.

The compressed fuel (methane) "CH4" with the ambient air "AIR" are fed into the reformer at temperature of $20^{\circ} \mathrm{C}$. The ratio of both streams is determined by a specified lambda coefficient required for the reformer. Then, the outlet stream from the reformer "FEED" is supplied to the anode side of the SOFC. A second stream of air "AIR-INLE" is supplied to the recuperator, then heated in the recuperator by the hot gas stream "BURN-OFF" from the burner. High temperature air "O2" enters the cathode side of SOFC and electrochemically reacts with fuel "FEED" supplied from the anode side of SOFC. Exhaust gas from the SOFC "A-OFF" is burnt with the cathode off gas "C-OFF-1" in the burner. The construction of each of the components is described below.

\section{Reformer}

An Aspen Plus equilibrium reactor module RGibbs (named "REFORMER") is selected to simulate the reforming reactions occurring inside the reformer. The methane is converted in the adiabatic reformer by catalytic partial oxidation reactions, which result in a temperature increase of the fuel gas. 


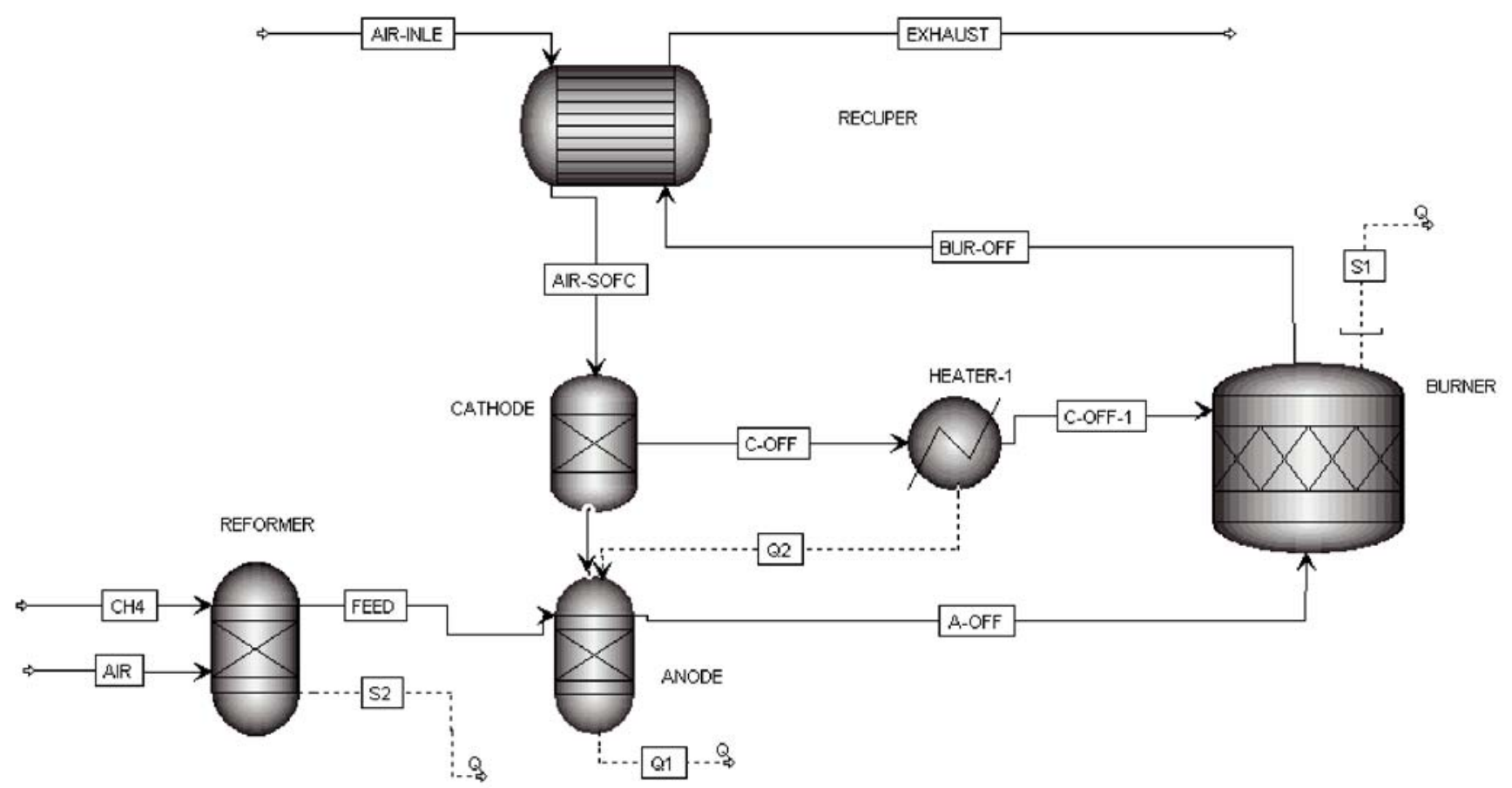

Figure 1. SOFC based system layout

The molar flow rate of the fresh fuel is equal to $0.001201392\left[\mathrm{kmol} \cdot \mathrm{h}^{-1}\right]$.

The chemical reactions specified in the reformer block are:

$$
\begin{aligned}
& \mathrm{CH}_{4}+0.5 \mathrm{O}_{2} \rightarrow \mathrm{CO}+2 \mathrm{H}_{2} \\
& \mathrm{CH}_{4}+2 \mathrm{O}_{2} \rightarrow \mathrm{CO}_{2}+2 \mathrm{H}_{2} \mathrm{O} \\
& 2 \mathrm{H}_{2}+\mathrm{O}_{2} \rightarrow 2 \mathrm{H}_{2} \mathrm{O} \\
& 2 \mathrm{CO}+\mathrm{O}_{2} \rightarrow 2 \mathrm{CO}_{2}
\end{aligned}
$$

The value of the lambda coefficient is calculated to meet the desired oxygen/carbon, $\mathrm{O} / \mathrm{C}$ ratio value using Aspen Plus Calculator C-2 function. The desired O/C ratio value is equal to 0.61 . The temperature and composition of the stream leaving "REFORMER" (stream "FEED") is calculated automatically by Aspen Plus. The temperature is generally above $600^{\circ} \mathrm{C}$ to avoid large temperature gradients in the stack assuming that the operating SOFC temperature is equal roughly to $800^{\circ} \mathrm{C}$. The syngas produced in the reformer and the oxidant are supplied to the fuel cell modelled through the "CATHODE", "ANODE" and "HEATER-1" units, where the electrochemical reaction takes place producing the demanded electrical power.

\section{Air stream preheating and oxygen supply to the cathode}

The SOFC stack inlet air "AIR-INLE" is preheated by the hot exhaust gas from burner "BURN-OFF" and then enters the cathode "CATHODE" to provide oxygen for the electrochemical reactions. To simulate heating process inside the heat exchanger module Heat $X$ named "RECUPER" is used.

The "CATHODE" is designed to be modelled as a variable oxygen separator. The Separator block allow to split the inlet stream "AIR-SOFC" into oxygen "O2" sent to the anode and the cathode exhaust gas "C-OFF". The molar flow rate of the "AIR-SOFC" directed to the cathode is equal to $0.039456\left[\mathrm{kmol} \cdot \mathrm{h}^{-1}\right]$ and contains $21 \% \mathrm{O}_{2}$ and $79 \% \mathrm{~N}_{2}$.
The oxygen quantity provided by stream "O2" is calculated through a Calculator $C$ - 1 subroutine using an iterative procedure with target the fuel utilization set by the project partner as 0.86 and based on the anode fuel equivalent hydrogen molar flow rate, $\mathrm{n}_{\mathrm{H}_{2, \text { equivalent }}}$ :

$\mathrm{n}_{\mathrm{O}_{2, \text { required }}}=0.5 \cdot \mathrm{U}_{\mathrm{f}} \cdot \mathrm{n}_{\mathrm{H}_{2, \text { equivalent }}}$

The $\mathrm{n}_{\mathrm{H}_{2, \text { equivalent }}}$ is the equivalent hydrogen contained in the fresh fuel and can be calculated from Eq. (2):

$\mathrm{n}_{\mathrm{H}_{2, \text { equivalent }}}=\mathrm{n}_{\mathrm{H}_{2, \text { in }}}+\mathrm{n}_{\mathrm{CO}_{\text {in }}}+4 \cdot \mathrm{n}_{\mathrm{CH}_{4, \text { in }}}$

where: $\mathrm{n}_{\mathrm{H}_{2, \text { in }}}$ represents the molar flow rate of hydrogen contained in the fresh fuel, $\mathrm{n}_{\mathrm{CO}_{\text {in }}}$ represents the molar flow rate of $\mathrm{H}_{2}$ that could be produced from the $\mathrm{CO}$ contained in the fuel by the shift reaction (R7), $\mathrm{n}_{\mathrm{CH}_{4, \text { in }}}$ represents the molar flow rate of hydrogen that could be produced from the methane contained in the fresh fuel. The fuel utilization factor, $\mathrm{U}_{\mathrm{f}}$, is defined as follows:

$$
\mathrm{U}_{\mathrm{f}}=\frac{\mathrm{n}_{\mathrm{H}_{2, \text { consumed }}}}{\mathrm{n}_{\mathrm{H}_{2, \text { equivalent }}}}
$$

where: $\mathrm{n}_{\mathrm{H}_{2, \text { consumed }}}$ is the molar flow rate of hydrogen consumed in the electrochemical reaction (R5). The molar flow rate of the oxygen "O2" directed from the cathode to the anode is equal to $0.001436144\left[\mathrm{kmol} \cdot \mathrm{h}^{-1}\right]$. The heat provided to the oxygen stream by the electrochemical reaction is considered by taking a heat stream "Q2" from the "HEATER-1" block directed to the "ANODE" block.

\section{Internal reforming and electrochemical reactions at the anode}

The pre-reformed fuel (stream "FEED") is fed to the "ANODE" block, where the remaining $\mathrm{CH}_{4}$ is reformed, $\mathrm{CO}$ is shifted and $\mathrm{H}_{2}$ is oxidized. The transfer of ions 
can not be modelled in Aspen Plus, therefore the overall reactions (R5) - (R9) instead of the cell half reactions were used in the "ANODE" block model:

$\mathrm{H}_{2}+0.5 \mathrm{O}_{2} \rightarrow \mathrm{H}_{2} \mathrm{O}$

$\mathrm{CH}_{4}+\mathrm{H}_{2} \mathrm{O} \rightarrow 3 \mathrm{H}_{2}+\mathrm{CO}$

$\mathrm{CO}+\mathrm{H}_{2} \mathrm{O} \rightarrow \mathrm{H}_{2}+\mathrm{CO}_{2}$

$\mathrm{H}_{2}+\mathrm{CO}_{2} \rightarrow \mathrm{CO}+\mathrm{H}_{2} \mathrm{O}$

$\mathrm{H}_{2} \mathrm{O} \rightarrow \mathrm{H}_{2}+0.5 \mathrm{O}_{2}$

The „ANODE” block is characterized by the equilibrium reactor module $R G i b b s$. The stoichiometry of the electrochemical reactions are based on the reactions (R5)-(R9). A constant value of pressure is assumed and equal to 1.035 [bar]. The outlet temperature of the exhaust gas "A-OFF" is calculated by using an Aspen Plus Design-Specs DS-1 function. The Design-Specs DS-1 function specifies that the electrical power equals and the total of heat losses equal to 100 [W] and 21 [W], respectively. Finally, it is assumed that the heat losses generated in the system are split equally (each of 7 [W]) and are represented by the heat loss: "S2" from the reformer and "S1" from the burner, respectively. The heat stream "Q1" from the anode included 100 [W] of electrical power and 7 [W] of heat losses. To determine the heat losses in the system is responsible the block Calculator $C$-4. The application of the block Calculator C-4 is also required due to the heat "Q2" calculation performed by specifying that the temperature of the depleted air stream "C-OFF-1" has to be equal to the temperature of the anode off gas "A-OFF", i.e. the heat value of $\mathrm{Q} 2=-73,60[\mathrm{~W}]$ for $\mathrm{FU}=0,86[-]$. The outlet temperatures of the anode and cathode exhausted gases should have roughly similar values to avoid high temperature gradients, which may lead to fuel cell damage. Therefore, to uniform temperatures additional Heater module named "HEATER-1" is used to simulate the heat exchange process. The appropriate amount of the heat provided to the stream is calculated by the function TRANSFER T-2.

\section{Burner}

The rest of the depleted exhausted gaseous from the anode and cathode after the electrochemical and chemical reactions are directed to the burner. To simulate the combustion process under adiabatic condition an Aspen Plus reactor module RStoic named "BURNER" is chosen. The remaining $\mathrm{H}_{2}$ and $\mathrm{CO}$ in the depleted fuel gaseous react with the oxygen assuming completion conversion according to the following reactions:

$\mathrm{H}_{2}+0.5 \mathrm{O}_{2} \rightarrow \mathrm{H}_{2} \mathrm{O}$

$\mathrm{CO}+0.5 \mathrm{O}_{2} \rightarrow \mathrm{CO}_{2}$

The outlet stream named "BURN-OFF" is directed to the heat exchange named "RECUPER" and is used to exchange the heat with the "AIR-INLE" stream delivered to the system at inlet temperature of $20^{\circ} \mathrm{C}$.

\section{Mathematical models}

Mathematical models include the heat and mass transfer characteristics of each component of the SOFC based system. The main assumptions used in the simulations are as follows:

- fuel cell module operates at steady stage,
- the air supplied to the system is composed of 79 [\%] $\mathrm{N}_{2}$ and $21[\%] \mathrm{O}_{2}$,

- the fuel supplied to the system is pure methane $\mathrm{CH}_{4} 100$ [\%],

- all chemical components of working fluids are treated as ideal gases,

- ideal heat exchanger,

- pressure drops are neglected,

- the free Gibbs energy is minimized in all the chemical reactions,

- pressure of 1.035 [bar] is considered.

\section{The SOFC electrochemistry}

The cell voltage is the most important aspect of any fuel cell modelling. The method that is adopted in the proposed model can be found in the references, ${ }^{2,3}$. It utilizes a performance curve, which is obtained by interpolation of experimental data at standard operating conditions as the reference point and it predicts the cell voltage using semi-empirical correlations. This approach provides a way to predict the fuel cell performance that can be easily implemented in Aspen Plus using a Define-Spec-Vary block function. The actual voltage was calculated from Eq. (4):

$\mathrm{V}=\mathrm{V}_{\mathrm{N}}-\mathrm{V}_{\text {Ohm }}-\mathrm{V}_{\text {Act }}-\mathrm{V}_{\text {Conc }}$

where: $V_{N}$ is the Nernst voltage equation, $V_{\mathrm{Ohm}}-\mathrm{Ohmic}$ voltage loss, $\mathrm{V}_{\text {Act }}$ - activation loss and $\mathrm{V}_{\text {Conc }}$ - concentration loss. The reversible Nernst voltage, $\mathrm{V}_{\mathrm{N}}$, was determined from Eq. (5):

$\mathrm{V}_{\mathrm{N}}=\mathrm{E}_{0}+\frac{\mathrm{RT}}{2 \mathrm{~F}} \ln \left(\frac{\mathrm{P}_{\mathrm{H}_{2}} \mathrm{P}_{\mathrm{O}_{2}}^{0.5}}{\mathrm{P}_{\mathrm{H}_{2} \mathrm{O}}}\right)$

where: $\mathrm{E}_{0}$ is the reversible potential $\left[\mathrm{J} \cdot \mathrm{mol}^{-1}\right]$ at standard conditions of 1 [bar], 2 represents the number of electrons produced per mole of hydrogen fuel reacted, $\mathrm{F}$ is the Faraday constant, $\mathrm{F}=96485\left[\mathrm{C} \cdot \mathrm{mol}^{-1}\right]$, T is the average SOFC temperature $[\mathrm{K}], \mathrm{R}$ is the molar gas constant, $\mathrm{R}=8.314\left[\mathrm{~J} \cdot \mathrm{mol}^{-1} \mathrm{~K}^{-1}\right], \mathrm{P}_{\mathrm{i}}$ is the partial pressure of gaseous $\mathrm{i}$ - component [bar]. The reversible potential, $\mathrm{E}_{0}$, was determined from Eq. (6) ${ }^{\mathbf{1 8}}$ :

$\mathrm{E}_{0}=\frac{4187 \cdot\left(58.3-\left(0.0113+9.6 \cdot 10^{-7} \cdot \mathrm{T}\right) \cdot \mathrm{T}\right)}{2 \mathrm{~F}}$

The Ohmic loss, which is the voltage loss due to the resistance, $r$, to electron flow through the anode and cathode as well as the interconnection and the resistance to ion flow through the electrolyte was calculated using Eq. (7):

$\mathrm{V}_{\text {Ohm }}=\frac{\mathrm{i}_{\text {cell }}}{\mathrm{A}_{\text {cell }}}\left(\mathrm{r}_{\text {anode }}+\mathrm{r}_{\text {cathode }}+\mathrm{r}_{\text {interconnectors }}+\mathrm{r}_{\text {electrolyte }}\right)$

According to the reference ${ }^{14}$ the Ohmic loss based on Eq. (8):

$$
\begin{aligned}
& \mathrm{V}_{\text {Ohm }}=\frac{\mathrm{i}_{\text {cell }}}{\mathrm{A}_{\text {cell }}}\left(\sigma_{\text {anode }} \cdot 1_{\text {anode }}+\sigma_{\text {cathode }} \cdot 1_{\text {cathode }}+\right. \\
& \left.+\sigma_{\text {interconn }} \cdot 1_{\text {interconn }}+\sigma_{\text {electrolyte }} \cdot 1_{\text {electrolyte }}\right)
\end{aligned}
$$


where: $i_{\text {cell }}$ is the cell current [A], $A_{\text {cell }}$ is the total active cell surface $\left[\mathrm{m}^{2}\right], \mathrm{l}_{\mathrm{i}}$ is the $\mathrm{i}$ - component thickness $[\mathrm{m}], \sigma_{\mathrm{i}}$ is the $\mathrm{i}$-component conductivity calculated as a function of temperature (Eqs. (9)-(12)):

$$
\begin{aligned}
& \sigma_{\text {anode }}=2.98 \cdot 10^{-5} \exp \left(-\frac{1392}{\mathrm{~T}}\right) \\
& \sigma_{\text {cathode }}=8.114 \cdot 10^{-5} \exp \left(\frac{600}{\mathrm{~T}}\right)
\end{aligned}
$$

$\sigma_{\text {interconnectors }}=1.2568 \cdot 10^{-3} \exp \left(\frac{4690}{\mathrm{~T}}\right)$

$\sigma_{\text {electrolyte }}=2.94 \cdot 10^{-5} \exp \left(\frac{10350}{\mathrm{~T}}\right)$

The cell current was calculated from Eq. (13):

$\mathrm{i}_{\text {cell }}=4 \cdot \mathrm{F} \cdot \mathrm{n}_{\mathrm{O}_{2 \text { required }}}$

The activation loss is the voltage loss as a result of the energy barrier that must be overcome by the reacting species. At low and medium operating temperatures, the activation loss has a significant influence on the current voltage drop. With temperature increase the influence of the activation loss decreases. The activation loss is higher for the cathode due to lower current density exchange value ${ }^{\mathbf{1 5}}$. The activation voltage loss in Aspen Plus is calculated using Eq. (14) ${ }^{\mathbf{1 6}}$ :

$\mathrm{V}_{\text {act }}=\left(\frac{\mathrm{RT}}{\mathrm{n} \beta \mathrm{F}}\right) \ln \left(\frac{\mathrm{j}}{\mathrm{j}_{0, \text { anode }}}\right)-\left(\frac{\mathrm{RT}}{\mathrm{n} \beta \mathrm{F}}\right) \ln \left(\frac{\mathrm{j}}{\mathrm{j}_{0, \text { cathode }}}\right)$

Where: $\beta$ is the conversion energy coefficient into electrical one, $\mathrm{j}_{0}$ is the exchange current density given as follows (Eqs. (15)-(16)) $)^{4}$ :

$\mathrm{j}_{0, \text { anode }}=\mathrm{j}_{\mathrm{H}_{2}}^{*} \cdot\left(\frac{\mathrm{P}_{\mathrm{H}_{2}}}{\mathrm{P}_{\text {ref }}}\right) \cdot\left(\frac{\mathrm{P}_{\mathrm{H}_{2} \mathrm{O}}}{\mathrm{P}_{\text {ref }}}\right) \cdot \exp \left(-\frac{\mathrm{E}_{\text {anode }}}{\mathrm{RT}}\right)$

$\mathrm{j}_{0 \text {,cathode }}=\mathrm{j}_{\mathrm{O}_{2}}^{*} \cdot\left(\frac{\mathrm{P}_{\mathrm{O}_{2}}}{\mathrm{P}_{\text {ref }}}\right)^{0.25} \cdot \exp \left(-\frac{\mathrm{E}_{\text {cathode }}}{\mathrm{RT}}\right)$

where: $\mathrm{P}$ is the system reference pressure, $\mathrm{P}_{\text {ref }}=1$ [bar], $\mathrm{P}_{\mathrm{i}}$ is the $\mathrm{i}$ - component partial pressure, $\mathrm{E}_{\text {anode/cathode }}$ is the anode or cathode energy activation $\left[\mathrm{J} \cdot \mathrm{mol}^{-1}\right], \mathrm{j}^{*}$ is the pre-exponential factor $\left[\mathrm{A} \cdot \mathrm{m}^{-2}\right]$.

Then, the value from the Eq. (14) should be compared with the previous calculated value of the current density from Eq. (17):

$\mathrm{j}=\frac{\mathrm{i}_{\text {cell }}}{\mathrm{A}_{\text {cell }}}$

The tolerance of error should be less than 0.5 [\%].

The concentration loss due to mass transfer limitations in the porous electrodes was modelled using Eqs. (18)-(20):

$\mathrm{V}_{\text {Conc }}=\mathrm{V}_{\text {Conc_anode }}+\mathrm{V}_{\text {Conc_cathode }}$

$\mathrm{V}_{\text {Conc_anode }}=-\frac{\mathrm{RT}}{2 \mathrm{~F}} \ln \left(1-\frac{\mathrm{j}}{\mathrm{j}_{\text {lim Anode }}}\right)+$

$+\frac{\mathrm{RT}}{2 \mathrm{~F}} \ln \left(1+\frac{\mathrm{P}_{\mathrm{H}_{2}} \cdot \mathrm{j}}{\mathrm{P}_{\mathrm{H}_{2}} \cdot \mathrm{j}_{\text {lim Anode }}}\right)$
$\mathrm{V}_{\text {Conc_cathode }}=-\frac{\mathrm{RT}}{4 \mathrm{~F}} \ln \left(1-\frac{\mathrm{j}}{\mathrm{j}_{\text {limCathode }}}\right)$

where: $\mathrm{j}_{\text {lim }}$ is the current density which can be obtained with maximum fuel consumption during the reaction. The following Eqs. (21) and (22) were used for the anode and cathode current density, respectively:

$$
\begin{aligned}
& \mathrm{j}_{\text {lim Anode }}=\frac{2 \cdot \mathrm{F} \cdot \mathrm{D}_{\text {eff }, \mathrm{H}_{2}-\mathrm{H}_{2} \mathrm{O}}}{\mathrm{R} \cdot \mathrm{T} \cdot \mathrm{1}_{\text {anode }}} \mathrm{P}_{\mathrm{H}_{2}} \\
& \mathrm{j}_{\text {lim Cathode }}=\frac{4 \cdot \mathrm{F} \cdot \mathrm{D}_{\text {eff }, \mathrm{O}_{2}-\mathrm{N}_{2}}}{\mathrm{R} \cdot \mathrm{T} \cdot 1_{\text {cathode }}\left(\mathrm{P}-\frac{\mathrm{P}_{\mathrm{O}_{2}}}{\mathrm{P}}\right)} \mathrm{P}_{\mathrm{O}_{2}}
\end{aligned}
$$

where: $\mathrm{D}_{\text {eff, }}$ is the overall effective diffusion coefficient for each gas was calculated using Eqs. (23)-(24):

$$
\begin{aligned}
& \mathrm{D}_{\mathrm{eff}, \mathrm{H}_{2}-\mathrm{H}_{2} \mathrm{O}}=\frac{\varepsilon}{\tau} \mathrm{D}_{\mathrm{H}_{2}-\mathrm{H}_{2} \mathrm{O}} \\
& \mathrm{D}_{\mathrm{eff}, \mathrm{O}_{2}-\mathrm{N}_{2}}=\frac{\varepsilon}{\tau} \mathrm{D}_{\mathrm{O}_{2}-\mathrm{N}_{2}}
\end{aligned}
$$

where: $\mathrm{D}_{\mathrm{ik}}$ is the ordinary binary diffusion coefficient for both anode and cathode (Eqs. (25)-(26)):

$$
\begin{gathered}
\mathrm{D}_{\mathrm{H}_{2}-\mathrm{H}_{2} \mathrm{O}}=\frac{0.00143 \cdot \mathrm{T}^{1.75}}{\mathrm{M}_{\mathrm{H}_{2}-\mathrm{H}_{2} \mathrm{O}}^{0.5} \cdot\left(\vartheta_{\mathrm{H}_{2}}^{1 / 3}+\vartheta_{\mathrm{H}_{2} \mathrm{O}}^{1 / 3}\right)^{2} \cdot \mathrm{P}} \\
\mathrm{D}_{\mathrm{O}_{2}-\mathrm{N}_{2}}=\frac{0.00143 \cdot \mathrm{T}^{1.75}}{\mathrm{M}_{\mathrm{O}_{2}-\mathrm{N}_{2}}^{0.5} \cdot\left(\vartheta_{\mathrm{O}_{2}}^{1 / 3}+\vartheta_{\mathrm{N}_{2}}^{1 / 3}\right)^{2} \cdot \mathrm{P}}
\end{gathered}
$$

where: $\vartheta_{\mathrm{ik}}$ is the Fuller diffusion volume taken as 7.07; 12.7, 16.6 and 17.9 for $\mathrm{H}_{2}, \mathrm{H}_{2} \mathrm{O}, \mathrm{O}_{2}$ and $\mathrm{N}_{2}$, respectively ${ }^{16} . \mathrm{M}_{\mathrm{i}}$ is the molecular weight $\left[\mathrm{kg} \cdot \mathrm{kmol}^{-1}\right]$ for the gaseous component, $\varepsilon$ is the porosity and $\tau$ is the tortuosity of the electrodes.

$$
\begin{aligned}
\mathrm{M}_{\mathrm{H}_{2}-\mathrm{H}_{2} \mathrm{O}} & =\frac{2}{\frac{1}{\mathrm{M}_{\mathrm{H}_{2}}}+\frac{1}{\mathrm{M}_{\mathrm{H}_{2} \mathrm{O}}}} \\
\mathrm{M}_{\mathrm{O}_{2}-\mathrm{N}_{2}} & =\frac{2}{\frac{1}{\mathrm{M}_{\mathrm{O}_{2}}}+\frac{1}{\mathrm{M}_{\mathrm{N}_{2}}}}
\end{aligned}
$$

The terms included in Eqs. (4)-(24) are listed in Table 1. The model takes the desired power output as an input to calculate the corresponding voltage and current required to generate the power ${ }^{\mathbf{1 3}}$. Based on the expected power the rest process parameters such as hydrogen and oxygen flow rates, voltage and current density are determined. The flowchart of the cell voltage calculations applied in this study can be found in paper ${ }^{3}$. 
Table 1. Model input parameters

\begin{tabular}{|l|c|c|}
\hline Model Parameter & Value & Dimension \\
\hline Active fuel cell surface & 0.00163 & {$\left[\mathrm{~m}^{2}\right]$} \\
\hline Anode thickness & 0.00056 & {$[\mathrm{~m}]$} \\
\hline Cathode thickness & 0.000033 & {$[\mathrm{~m}]$} \\
\hline Electrolyte thickness & 0.00001 & {$[\mathrm{~m}]$} \\
\hline Interconnection thickness & 0.0017 & {$[\mathrm{~m}]$} \\
\hline $\begin{array}{l}\text { Activation energy for } \\
\text { anode/cathode }\end{array}$ & $110000 / 120000$ & {$\left[\mathrm{~J} \cdot \mathrm{mol}^{-1}\right]$} \\
\hline Electrode porosity & 0.35 & {$[-]$} \\
\hline Tortuosity & 3.8 & {$[-]$} \\
\hline $\begin{array}{l}\text { Pre-exponential factor } \\
\text { anode/cathode }\end{array}$ & $2.07 \cdot 10^{9} / 5.19 \cdot 10^{8}$ & {$\left[\mathrm{~A} \cdot \mathrm{m}^{-2}\right]$} \\
\hline
\end{tabular}

\section{RESULTS AND DISCUSSION}

The Aspen Plus model developed was validated by comparison with the literature results. From Figure 2 it can be seen that the deviation between the simulation and literature ${ }^{17}$ results is noticeable, but acceptable. Increasing the current density from 1000 to $6000\left[\mathrm{~A} \cdot \mathrm{m}^{-2}\right]$ decrease voltage, but increases power (see Fig. 3). Voltage is lowered significantly as a result of voltage losses.

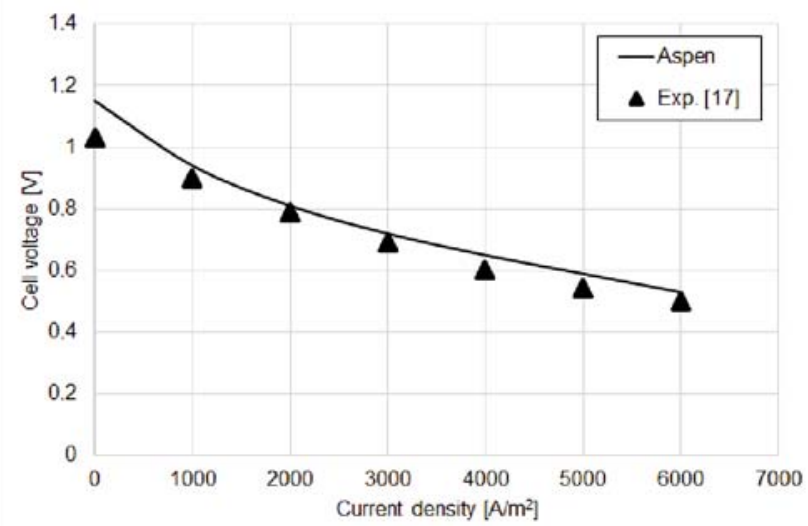

Figure 2. Comparison of polarisation curves from the simulation and literature ${ }^{\mathbf{1 7}}$

The major calculation results are shown in Table 2.

The inlet fuel composition was set to $\mathrm{CH}_{4} 100 \%$. The inlet air temperature was set as $20^{\circ} \mathrm{C}$, while the fuel temperature was equal to $665^{\circ} \mathrm{C}$. The SOFC deliver $121[\mathrm{~W}]$ power. The summary of values for each block of system can be found in Table 3 .

Another point of interest was the influence of single parameter variation on the efficiency of the SOFCs based power generation system. Thus, the influence of fuel utilization, $\mathrm{FU}$, and catalytic partial oxidation, $\mathrm{CPO}_{x}$, air ratio, $\lambda$, was investigated under constant conditions of other system parameters during the unsteady-state simulations. In the first step of dynamic analysis response

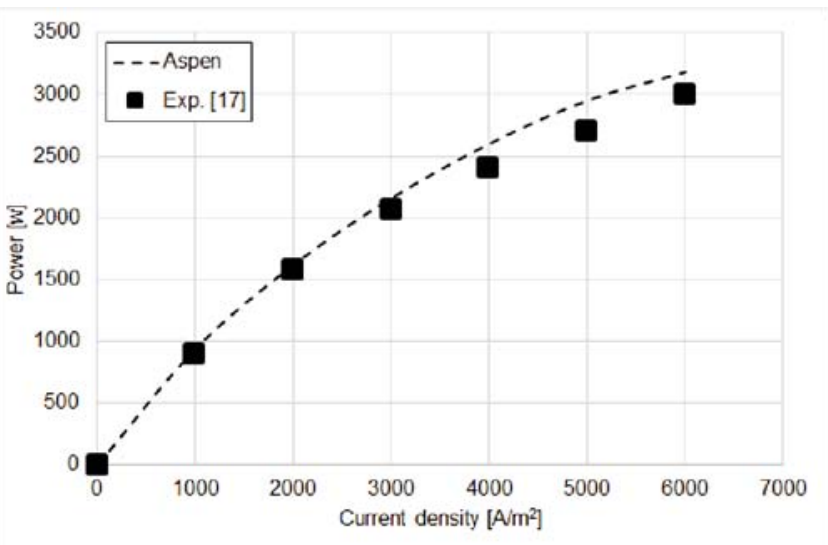

Figure 3. Current density vs. power

Table 3. SOFC model simulation results

\begin{tabular}{|l|c|c|}
\hline Block & $\mathrm{T}\left[^{\circ} \mathrm{C}\right]$ & $\mathrm{P}[\mathrm{bar}]$ \\
\hline REFORMER & 664.85 & 1.035 \\
\hline ANODE & 845.12 & 1.035 \\
\hline CATHODE & 635.00 & 1.035 \\
\hline HEATHER-1 & 845.12 & 1.035 \\
\hline BURNER & 913.28 & 1.035 \\
\hline
\end{tabular}

of the SOFC system for fuel utilization variation was considered. The fuel utilization factor, FU, is one of the most important operating parameters for SOFCs and has a significant impact on the cell voltage as it can be seen in Figure 4. The starting value of the fuel utilization was equal to 0.86 , then the FU decreases to 0.60 and stays at this level for two hours. Finally, the value of the fuel utilization was increased to its initial value of 0.86 (between the 5th working hour and 6th one). Decreasing the fuel utilization from 0.86 to 0.60 leads to a decrease of the cell voltage from 0.95 [V] to $0.75[\mathrm{~V}]$. Further increasing fuel utilization from 0.60 to the initial stage leads to return to the voltage of 0.95 $[\mathrm{V}]$ with accompanying temporary growth of the anode off stream temperature to $871^{\circ} \mathrm{C}$, which was even higher than initial temperature equal to $851^{\circ} \mathrm{C}$. It should be underlined that such temperature increase can be particularly dangerous, if SOFCs are operating close to the temperature above which the fuel cells can be damaged due to thermal stresses. Therefore, in further analysis a special attention will be paid to required operating conditions to ensure slower return of parameters to initial stage after short-term deviation.

The influence of $\mathrm{CPO}_{\mathrm{x}}$ air ratio, $\lambda$, was also investigated during the simulations in the range of 0.61 at the AIR mole flow rate of $0.00349\left[\mathrm{kmol} \cdot \mathrm{h}^{-1}\right]$ to $\lambda=0.80$ at the AIR mole flow rate of $0.00458\left[\mathrm{kmol} \cdot \mathrm{h}^{-1}\right]$ per 60 minutes. After two hours the system slowly return

Table 2. SOFC model simulation results

\begin{tabular}{|c|c|c|c|c|c|c|c|c|c|c|}
\hline \multirow{2}{*}{ Stream no. } & \multirow{2}{*}{$\begin{array}{c}\mathrm{T} \\
{\left[{ }^{\circ} \mathrm{C}\right]}\end{array}$} & \multirow{2}{*}{$\begin{array}{c}\mathrm{P} \\
{[\mathrm{bar}]}\end{array}$} & \multirow{2}{*}{$\begin{array}{c}\mathrm{F} \\
{\left[\mathrm{kmol} \cdot \mathrm{h}^{-1}\right]}\end{array}$} & \multicolumn{7}{|c|}{ Gas composition $\left[\mathrm{mol}^{\prime} \mathrm{mol}^{-1}\right]$} \\
\hline & & & & $\mathrm{H}_{2}$ & $\mathrm{CH}_{4}$ & $\mathrm{H}_{2} \mathrm{O}$ & $\mathrm{CO}$ & $\mathrm{CO}_{2}$ & $\mathrm{O}_{2}$ & $\mathrm{~N}_{2}$ \\
\hline $\mathrm{CH}_{4}$ & 20 & 1.035 & 0.001 & - & 1 & - & - & - & - & - \\
\hline AIR & 20 & 1.035 & 0.003 & - & - & - & - & - & 0.21 & 0.79 \\
\hline AIR-INLE & 20 & 1.035 & 0.039 & - & - & - & $\overline{-}$ & - & 0.21 & 0.79 \\
\hline FEED & 665 & 1.035 & 0.006 & 0.308 & 0.026 & 0.037 & 0.140 & 0.032 & 0 & 0.456 \\
\hline AIR-SOFC & 635 & 1.035 & 0.039 & - & - & - & - & - & 0.21 & 0.79 \\
\hline C-OFF & 635 & 1.035 & 0.038 & - & - & - & - & - & 0.18 & 0.82 \\
\hline A-OFF & 845 & 1.035 & 0.006 & 0.051 & $2.6 \cdot 10^{-8}$ & 0.326 & 0.027 & 0.162 & 0 & 0.433 \\
\hline C-OFF-1 & 845 & 1.035 & 0.038 & - & - & - & - & - & 0.18 & 0.82 \\
\hline BUR-OFF & 913 & 1.035 & 0.044 & 0 & $3.8 \cdot 10^{-9}$ & 0.054 & 0 & 0.027 & 0.149 & 0.768 \\
\hline EXHAUST & 412 & 1.035 & 0.044 & 0 & $3.8 \cdot 10^{-9}$ & 0.054 & 0 & 0.027 & 0.149 & 0.768 \\
\hline
\end{tabular}




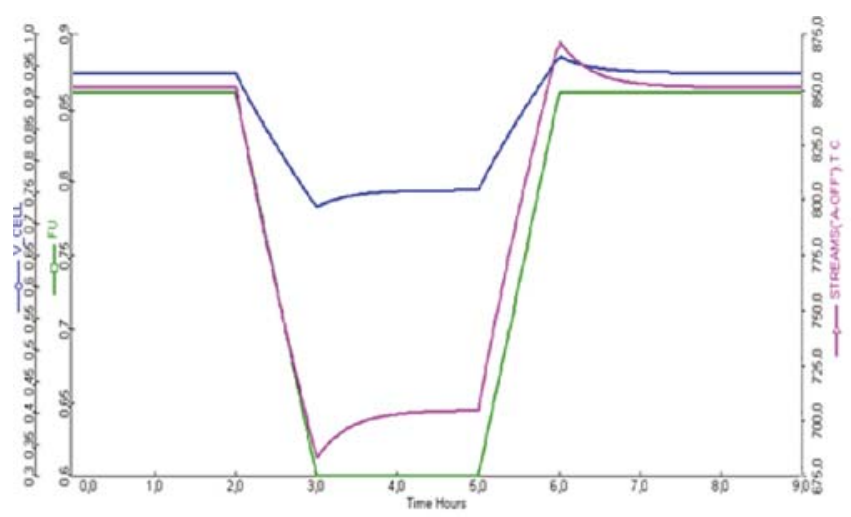

Figure 4. Dynamic response of the SOFCs system for different values of fuel utilization at constant value of $\lambda=0.61[-], J=1000\left[\mathrm{~A} / \mathrm{m}^{2}\right]$

to the initial stage at the $\lambda=0.60$. The simulation was carried out at constant values of fuel utilization of 0.86 and current density of $1000\left[\mathrm{~A} \cdot \mathrm{m}^{-2}\right]$. The results reveal a less significant dependency between the cell voltage and $\mathrm{CPO}_{\mathrm{x}}$ air ratio variation in comparison to the previous case, when the fuel utilization variation was considered. The cell voltage slightly drops with increasing $\mathrm{CPO}_{\mathrm{x}}$ air ratio as shown in Figure 5. The lower the $\mathrm{CPO}_{\mathrm{x}}$ air ratio, the higher cell voltage was noticed and the higher

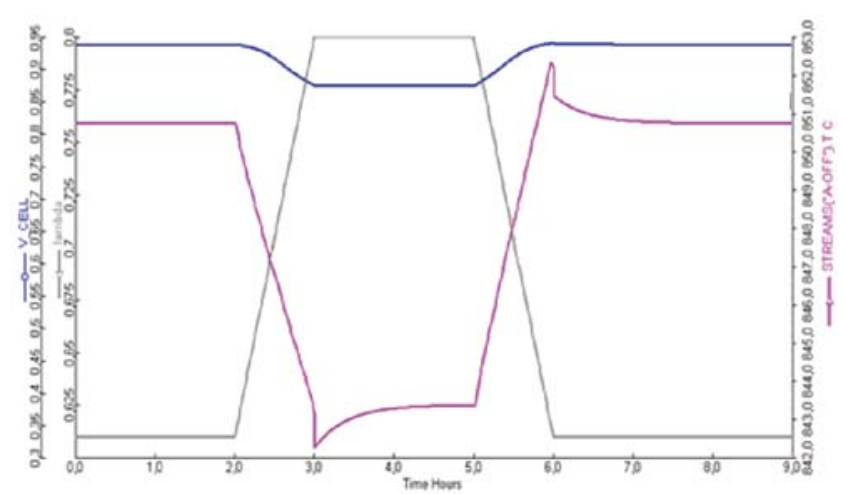

Figure 5. Dynamic response of the SOFCs system for different values of $\mathrm{CPO}_{\mathrm{x}}$ air ratio at constant value of $\mathrm{FU}=0.86[-], \mathrm{J}=1000\left[\mathrm{~A} / \mathrm{m}^{2}\right]$

efficiency was achieved due to a higher amount of $\mathrm{CO}$ and $\mathrm{H}_{2}$ available in the fuel. In general, the efficiency of the SOFCs system was increasing with decreasing the $\mathrm{CPO}_{\mathrm{x}}$ air ratio, but it should be underlined that a reduction of the $\mathrm{CPO}_{\mathrm{x}}$ air ratio is limited by the anode inlet temperatures that can not be lower than $650^{\circ} \mathrm{C}$ due to the risk of carbon formation.

\section{CONCLUSIONS}

SOFCs based power generated system model at the steady-state and unsteady-state using Aspen Tech tool was developed and validated with literature data. The developed model used existing Aspen Plus/Aspen Dynamics functions in combination with user defined subroutines. The model allows detailed thermodynamics and electrochemical description of the SOFCs behaviour. Although, there were some deviations in the lowest current density points, the simulation results obtained from the process simulator shows that the developed model can predict the SOFCs system performance successfully.

\section{NOMENCLATURE}

$A_{\text {cell }} \quad-$ total active fuel cell surface $\left[\mathrm{m}^{2}\right]$

$\mathrm{D}_{\mathrm{i}, \mathrm{k}} \quad-$ ordinary binary diffusion coefficient $\left[\mathrm{m}^{2} \mathrm{~s}^{-1}\right]$

$\mathrm{D}_{\text {eff,i }} \quad-$ overall effective diffusion coefficient for $\mathrm{i}$ - component $\left[\mathrm{m}^{2} \mathrm{~s}^{-1}\right]$

$\mathrm{E}_{\text {anode/cathode }}$ - anode or cathode energy activation $\left[\mathrm{J} \cdot \mathrm{mol}^{-1}\right]$

$\mathrm{F} \quad-$ Faraday's constant $\left[\mathrm{C} \cdot \mathrm{mol}^{-1}\right]$

$\mathrm{G}_{\mathrm{i}}{ }^{0} \quad-$ molar Gibbs free energy of formation $\mathrm{i}$ - component $\left[\mathrm{J} \cdot \mathrm{mol}^{-1}\right]$

$\mathrm{i}_{\text {cell }} \quad-$ cell current $[\mathrm{A}]$

$\mathrm{i} \quad-$ species $\mathrm{H}_{2}, \mathrm{H}_{2} \mathrm{O}, \mathrm{O}_{2}[-]$

j $\quad-$ density current $\left[\mathrm{A} \cdot \mathrm{m}^{-2}\right]$

$\mathrm{j}_{0} \quad-$ exchange density current $\left[\mathrm{A} \cdot \mathrm{m}^{-2}\right]$

$\mathrm{j}^{*} \quad-$ pre-exponential factor $\left[\mathrm{A} \cdot \mathrm{m}^{-2}\right]$

$\mathrm{j}_{\lim } \quad-$ current density at maximum fuel consumption $\left[\mathrm{A} \cdot \mathrm{m}^{-2}\right]$

$1_{\text {anode }} \quad-$ anode thickness [m]

$1_{\text {cathode }} \quad-$ cathode thickness [m]

$1_{\text {electrolyte }} \quad-$ electrolyte thickness [m]

$1_{\text {interconn }} \quad-$ interconnectors thickness $[\mathrm{m}]$

$\mathrm{M}_{\mathrm{i}} \quad-$ molar mass of species $i\left[\mathrm{~kg} \cdot \mathrm{mol}^{-1}\right]$

$\mathrm{n}_{\mathrm{CH}_{4, \text { in }}} \quad-$ molar flow rate of $\mathrm{H}_{2}$ that could be produced from the $\mathrm{CH}_{4}\left[\mathrm{~mol} \cdot \mathrm{s}^{-1}\right]$

$\mathrm{n}_{\mathrm{CO}_{\text {in }}} \quad-$ molar flow rate of $\mathrm{H}_{2}$ that could be produced from the $\mathrm{CO}\left[\mathrm{mol} \cdot \mathrm{s}^{-1}\right]$

$\mathrm{n}_{\mathrm{H}_{2, \text { consumed }}} \quad-$ molar flow rate of $\mathrm{H}_{2}$ consumed $\left[\mathrm{mol} \cdot \mathrm{s}^{-1}\right.$ ]

$\mathrm{n}_{\mathrm{H}_{2, \text { equivalent }}}$ - equivalent $\mathrm{H}_{2}$ molar flow rate $\left[\mathrm{mol} \cdot \mathrm{s}^{-1}\right.$ ]

$\mathrm{n}_{\mathrm{H}_{2, \text { in }}} \quad-$ molar flow rate of $\mathrm{H}_{2}\left[\mathrm{~mol} \cdot \mathrm{s}^{-1}\right]$

$\mathrm{n}_{\mathrm{H} 2 \text {, required }}-$ required $\mathrm{O}_{2}$ molar flow rate $\left[\mathrm{mol} \cdot \mathrm{s}^{-1}\right.$ ]

$\mathrm{P} \quad-$ pressure [bar]

$\mathrm{P}_{\mathrm{i}} \quad-$ partial pressure of gaseous

i - component [bar]

$\mathrm{P}_{\text {ref }} \quad-$ system reference pressure [bar]

$\mathrm{R} \quad-$ universal gas constant $\left[\mathrm{Jkmol}^{-1} \mathrm{~K}^{-1}\right]$

$\mathrm{r}_{\text {anode }} \quad-$ anode resistance $[\Omega]$

$\mathrm{r}_{\text {cathode }} \quad$ - cathode resistance $[\Omega]$

$\mathrm{r}_{\text {electrolyte }} \quad-$ electrolyte resistance $[\Omega]$

$\mathrm{r}_{\text {interconnectors }} \quad-$ interconnectors resistance $[\Omega]$

$\mathrm{T} \quad-$ temperature $[\mathrm{K}]$

$\mathrm{U}_{\mathrm{f}} \quad-$ fuel utilization factor [-]

$\mathrm{V} \quad-$ voltage [V]

$\mathrm{V}_{\text {Act }} \quad-$ activation loss [V]

$\mathrm{V}_{\text {Conc }} \quad-$ concentration loss [V]

$\mathrm{V}_{\mathrm{N}} \quad-$ Nernst voltage [V]

$\mathrm{V}_{\mathrm{Ohm}} \quad-$ Ohmic voltage loss [V]

Greek symbols

$\beta-\quad$ conversion energy coefficient into electrical one $[-]$

$\tau \quad-$ tortuosity factor $[-]$

$\vartheta_{\mathrm{ik}} \quad-$ Fuller diffusion volume $\left[\mathrm{m}^{2} \cdot \mathrm{s}^{-1}\right]$

$\Delta \mathrm{G}^{0} \quad-$ molar Gibbs free energy of formation $\left[\mathrm{J} \cdot \mathrm{mol}^{-1}\right]$

\section{ACKNOWLEDGEMENTS}

The research programme leading to these results received funding from the European Union's Seventh 
Framework Programme (FP7/2007-2013) for the Fuel Cells and Hydrogen Joint Undertaking (FCH JU) under grant agreement $\mathrm{n}^{\circ}$ [621213]. Information contained in the paper reflects only view of the authors. The FCH JU and the Union are not liable for any use that may be made of the information contained therein. The work was also financed from the Polish research funds awarded for the project No. 3126/7.PR/2014/2 of international cooperation within STAGE-SOFC in years 2014-2017.

\section{LITERATURE CITED}

1. Facci, A.L., Cigolotti, V., Jannelli, E. \& Ubertini, S. (2017). Technical and economic assessment of a SOFC based energy system for combined cooling, heating and power. Appl. Energy, 192, 563-574. DOI: 10.1016/j.apenergy.2016.06.105.

2. Zhang, W., Croiset, E., Douglas, P.L., Fowler, M.W. \& Entchev, E. (2005). Simulation of tubular solid oxide fuel cell stack using AspenPlus ${ }^{\mathrm{TM}}$ unit operation models, Energy Conv. Managem. 46. 181-196. DOI: 10.1016/j.enconman.2004.03.002.

3. Ameri, M. \& Mohammadi, R. (2013). Simulation of an atmospheric SOFC and gas turbine hybrid system using Aspen Plus software. Inter. J. Energy Res. 37, 412-425. DOI: 10.1002/er.1941.

4. Anderson, T., Vijay, P. \& Tade, M.O. (2014). An adaptable steady state Aspen Hysys model for the methane fuelled solid oxide fuel cell. Chem. Enginee. Res. Design. 92, 295-307. DOI: 10.1016/j.cherd.2013.07.025.

5. Galvagno, A., Prestipino, M., Zafarana, G. \& Chiodo, V. (2016). Analysis of an integrated agro-waste gasification and $120 \mathrm{kw}$ SOFC CHP system: modeling and experimental investigation. Energia Proc. 101, 528-535. DOI: 10.1016/j. egypro.2016.11.067.

6. Doherty, W., Reynolds, A. \& Kennedy, D. (2010). Computer simulation of biomass gasification - Solid Oxide Fuel Cell power system using ASPEN Plus. Energy, 35, 4545-4555. DOI: 10.1016/j.energy.2010.04.051.

7. Song, T.W., Sohn, J.L., Kim, J.H., Kim, T.S., Ro, S.T., Suzuki, K. (2005). Performance analysis of a tubular solid Oxide fuel cell/micro gas turbine hybrid power system based on a quasi-two dimensional model. J. Power Sourc. 142, 30-42. DOI: 10.1016/j.jpowsour.2004.10.011.

8. Achenbach, E. (1994). Three-dimensional and time-dependent simulation of a planar solid oxide fuel cell stack. J. Power Sour. 49, 333-348. DOI: 10.1016/0378-7753(93)01833-4.

9. Chan, S.H., Khor, K.A. \& Xia, Z.T. (2001). A complete polarization model of a solid oxide fuel cell and its sensitivity to the change of cell component thickness. J. Power Sour. 93, 130-140. DOI: S0378-7753(00)00556-5.

10. Kupecki, J., Skrzypkiewicz, M., Wierzbicki, M. \& Stepien, M. (2015). Analysis of a micro-CHP unit with in-series SOFC stack fed by biogas. Energia Proc. 75, 2021-2026. DOI: 10.1016/j.egypro.2015.07.265.

11. Barelli, L., Bidini, G., Gallorini, F. \& Ottaviano, A. (2001). An energetic-exergetic comparison between PEMFC and SOFC based micro-CHP systems. Inter. J. Hydrogen Energy, 36, 2011, 3206-3214. DOI: 10.1016/j/ijhydene.2010.11.079.

12. Campanari, S. (2001). Thermodynamic model and parametric analysis of a tubular SOFC module. J. Power Sour. 92, 1-2, 26-34. DOI: S0378-7753(00)00494-8.

13. EG \& G. Services, Parsons Inc., Science Applications International Corporation, Fuel Cell Handbook, National Technical Information Service, U. S. Department of Commerce: Springfield, V A, 2004.

14. Akkaya, V.A. (2007). Electrochemical model for performance analysis of a tubular SOFC. Int. J. Energy Res. 31, 1, 79-98, DOI: 10.1002/er.1238.

15. Timothy, A., Periasamy, V. \& Moses, T. (2014). An adaptable steady state Aspen Hysys model for the methane fuelled solid oxide fuel cell. Chem. Enginee. Res. Des. 92, 295-307. DOI: 10.1016/j.cherd.2013.07.025.

16. Kakac, S., Pramuanjaroenkij, A. \& Zhou, X.Y. (2007). A review of numerical modeling of solid Oxide fuel cells. Inter. J. Hydrogen Energy, 32, 761-786, 2007. DOI: 10.1016/j. ijhydene.2006.11.028.

17. Majewski, A.J. \& Dhir, A. Silver as a current collector for SOFC, 12th European SOFC \& SOE Forum, ISBN 9783-905592-21-4, 5-8 July 2016, Lucerna, Switzerland.

18. Minutillo, M., Perna, A. \& Jannelli, E.(2014). SOFC and MCFC system level modelling for hybrid plants performance prediction, Inter. J. Hydrogen Energy. 39, 21688-21699. DOI: 10.1016/j.ijhydeme.2014.09.082. 